\title{
大腿四頭筋切除後患者の歩行分析について
}

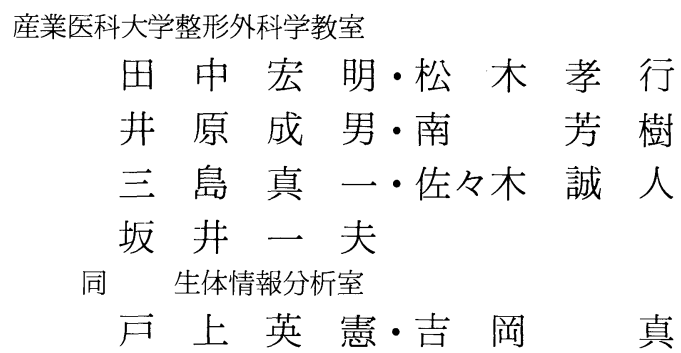

\section{Gait Analysis following Removal of Quadriceps Muscles for Resection of Tumor.}

by

Hiroaki Tanaka, Takayuki Matsuki, Nario Ihara, Yoshiki Minami, Shinichi Mishima, Makoto Sasaki and Kazuo Sakai.

Department of Orthopaedic Surgery, School of Medicine, University of Occupational and Environmental Health.

Hidenori Togami and Makoto Yoshioka

Analytical Labolatory of Human Information, School of Medicine,

University of Occupational and Environmental Health.

The patient was an 83-year-old woman who had noted swelling about the anterior aspect of the left thigh. The clinical diagnosis was a malignant soft tissue tumor and she underwent a radical resection of the left thigh which included the entire quadriceps muscles without reconstruction of extensor mechanism of the knee. But a few months after the operation, she walked well without a cane indoors and without her knee giving way. Gait analysis was performed using T.V. and floor reaction by force plate. We thought that the extensor mechanism of the knee was compensated for by the various muscles, and especially by the hip and ankle joints.

はじめに

大腿四頭筋は膝関節 extensor mechanismの最も 重要な構成体であり，その久損は大きな障害をもたら すと予想される。

今回我々は, 大腿部悪性軟部腫焬に対する広範囲切 除術として，大腿四頭筋を全て切除した患者を経験し た. 術後の ADL 特に歩行に対する障害を危惧したが， 患者は独歩可能となっている，歩行分析などを行い， 膝関節 extensor mechanism につて考察したので報 告する.
症例

83才の女性で，左大腿部腫瘤を主訴として来院した。 悪性軟部腫瘍と診断し，腫瘍を含め縫工筋，大腿直筋， 内側広筋，中間広筋，外側広筋と膝蓋骨を一塊とした 広範囲切除術を施行した. Extensor mechaism の再 建は行っていない. 病理学的診断は malignant fibrous his tiocy toma であった。創治癒後, 歩行訓練を開始し た。始めは簡単な膝関節伸展位固定装具を付け歩行さ せ，徐々に装具をはずしてゆき，術後 1 ケ月より固定 装具なしで 1 本杖歩行が叮能となった。 
術後13ケ月の時点で ADLの評価と歩行分析などを 行った。

膝関節は一 50 の伸展制限があり, 膝伸展筋ナ」はゼ口 である(表一1).

歩行動作は得時跛行があるが膝折れはなく転倒した

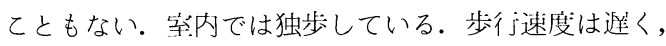
走ることはできない. 片足立.ち股関節屈曲位, 膝関節伸 展位にて支えがあれば 2 ～ 3 秒䦎叮能である(表一 2 ).

\begin{tabular}{|c|c|c|c|}
\hline \multirow{2}{*}{ ROM } & \multicolumn{3}{|c|}{ 関節可動域と筋力測定 } \\
\hline & $\mathrm{R}$ & \multicolumn{2}{|c|}{ L（患側） } \\
\hline hip & 正常 & 内旋, 外旋 & 軽度制限あり \\
\hline knee & & & \\
\hline extension & $0^{\circ}$ & & $=5^{\circ}$ \\
\hline flexion & $158^{\circ}$ & & $145^{\circ}$ \\
\hline ankle & 正常 & & 常 \\
\hline
\end{tabular}

\begin{tabular}{l|c|c} 
MMT & $\mathrm{R}$ & $\mathrm{L}$ \\
\hline knee extensor & 5 & $\underline{0}$ \\
knee flexor & 5 & 4 \\
hip extensor & 4 & 3
\end{tabular}

※他は 4 〜 5 レベルで左右差なし

\section{表 2 日掌生活動作の障害}

(1) 歩行動作 :

a) 跛行；学時あるが膝折れはない

b) 装具; 外出時のみ 1 本杖を使用

c) 歩行距離 ; $500 \mathrm{~m}$ 以内

d) 歩行速度；20 sec/10 m と避延

e) 走行; 不叮能

(2) トイレの使用：洋式トイレでは川能

（3）衣服の着脱：坐って行う

(4) 入浴動作：可能

（5）階段の昇降：1 本杖使用にて 1 段毎に足をそろえる 手すりは不要

(6) 片足立.ち：患側では支えがあれば $2 \sim 3$ 秒間可能

\section{歩 行 分 析}

(1)方法 (図一 - 1)

T. V. カメラによる観測と，同時にフォースプレート

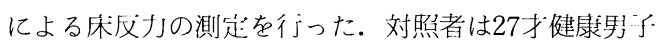
である. 次の身体上の 9 点に $1 \times 1 \mathrm{~cm}$ 大のマーカ一 (カラーテープで代朋) を付けた。第 5 MTPJ, 踵部,
足殿節外顆，腓䟫頭，大腿骨外側上顆，大転子，上前 腸省棘，上後腸骨棘と体幹中央部である。歩行路は水 米で中央に $40 \times 60 \mathrm{~cm}$ 大のフォースプレートが埋め込 まれている. T. V. カメラ(1)はフォースプレートより 3.2 $\mathrm{m}$ の位置に固定され，歩行動作を側方より撮影する.

T. V. カメラ(2)はフォースプレート下伍から床反才最大 作䏳点と足跡を撮影する.T.V.のサンプリング闆隔は $1 / 30$ 秒である. 撮影したビデオはVIDEO POSITION ANALYZERにより分析した。患者には歩きやすい力 デンス (76歩/分) で, 対照者には slow speed (カデ ンス60歩/分)と fast speed (カデンス114歩/分) で 歩行させ測定した。

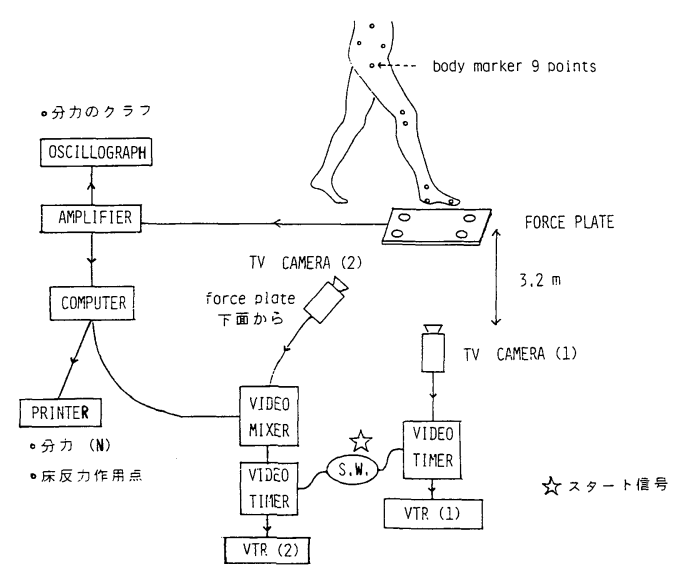

撮影・測定装置の搆成

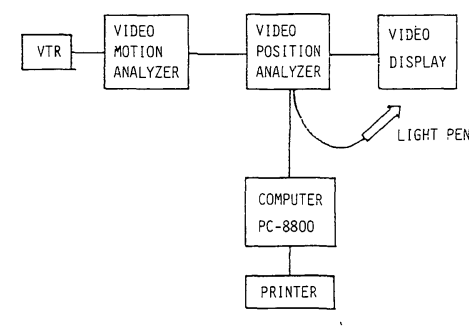

VIDEO POSITION A.HALYZER, に゙よるVTRの分析

$$
\text { 図一 } 1
$$

(2)絬果及び考察

身体諸点の軌跡：(汹一-2) は身体上の条点を結ん だ体幹，大腿，下腿と足部の軸を示すスティックピク チャーである．踵接地作湔からつま先離れ间後までの 

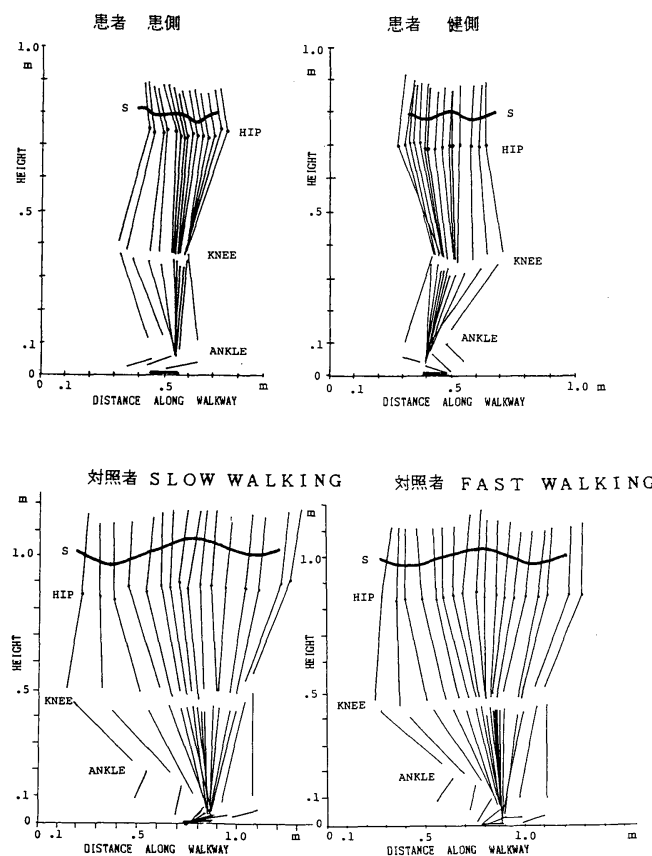

図一2 身体諸点の軌跡

動きを $100 \mathrm{msec}$ 開隔で描いてある. S の曲線は上前腸 筜棘の軌跡であり，重心の軌跡を亦すと考えだ． S は対照者 slow walking と患者の健側では，ゆるやか なサインカーブを描き，踵接地時に下降，市脚中期に 上秋，その後蹅離れ後再び上舁する，しかし患者患側 では踵接地時の下降後急に上舁し，立脚中期では一起 で下降することなく，つま先離れ後の上型へ移行する。 これは重心が下降する间前に健側が踵接地することで， 踏み切り時の膝折れを防いでいるものと考えられる.

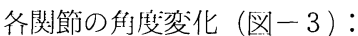

対照者 fast walking の膝関節では踵接地時一 $5^{\circ}$ ま で伸展し, その後屈曲, 立脚中期で再び伸展, 踵離れ 屈曲するという double knee actionがみられるが， 患者患側ではほぼ消失している，又立脚中期には徐々 に伸展運動が続き, 膝折れを示す所兒はない.

対照者股殿節では踵接地時に $10^{\circ} \sim 15^{\circ}$ 屈曲位にあり， 立脚中期には約 $20 \sim 25^{\circ}$ の伸展位，となり，つま先離れ

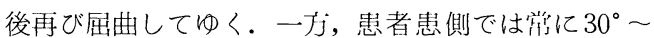
$40^{\circ}$ 屈曲位にある．また踵接地後徐々に伸展するが， 一旦屈曲したのちさ脚中期间前に急に伸展する（久印
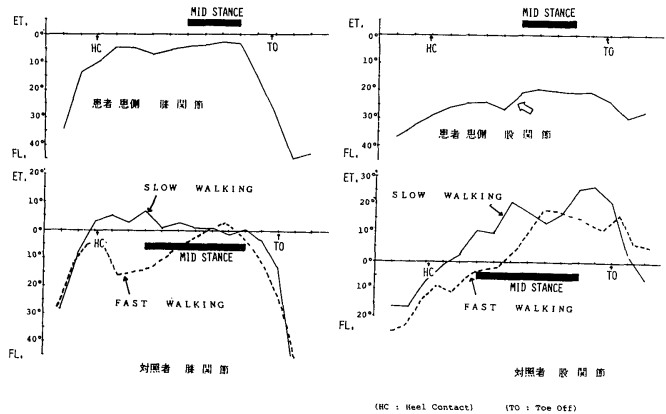

図一３各関節の角度変化

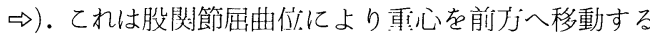
と同時に，股殿節の伸展連動により膝を後广うへ引くこ とで滕折れを防いでいるものと考えられる.

床反少（瓯一 -4)

内外側方们分才」では，患者患側と対照者 slow walking では差がなく，常に内側へ问ったJが働いている。

前後户问分才」は，対照者では 2 相性:のカーブを描き， 蹅接地以後の踏み込み時には後內への才働き, 踏み 切り時には前內゙への抽働いている，患者患側では 2 朴悱:のカーブは描かず，踵接地後の踏み込み動作がみ られない。乙れも滕折れ防止に役けっている。

垂问方们の分才小患者患側では台形の 2 つのピーク がイヘへずれ，立脚中期の始まりが進く，持続時閆も知 いととを示している.

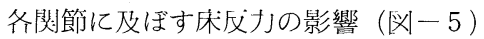

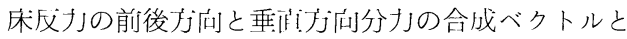
父䦌節，特に膝闒節との位置闒係をみた。 対照者 slow walkingでは蹅接地時はべクトル作湖点は踵部にあり， ベクトルは滕関節の後方を通過する。立脚中期以後, 作肚点はつま先に移り, ベクトルはほぼ膝関節を通過 し，つま先離れ時には再び膝関節後方を通過する。一 方患者患側の場合は，踵接地でベクトル作脚点はすで に足底中央部にあり，ベクトルは膝即節の前方を通邀 する．立脚中期以後作湖点はつま先近くに移動するが，

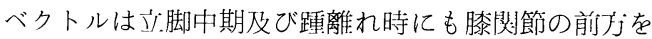
通過し，つま先離れ時に滕即節を通聥している，以上 のようにベクトルが膝関節後方を通過する時期のある 対照者と比較すると, 患側膝関節には伸展モーメント が働きやすい状態にあると言える゙”. 


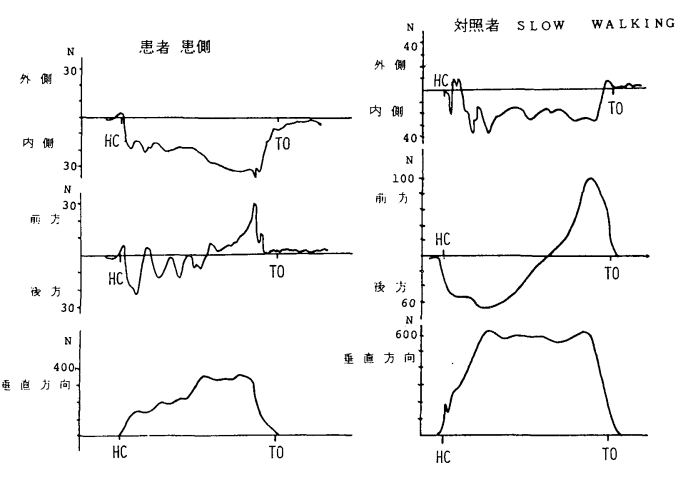

図一４ 床反力

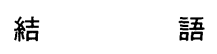

大腿四頭筋切除後患者の歩行分析を試みた. Extensor mechanismの再建は行ってないにもかかわらず, 膝関節は立脚中期（片足支持期）を通じて膝折れは起
っていない.この理由として，

（1）踵接地は足底全体で行い，前方への踏み込みが ない. この時すでに下腿三頭筋により膝を後方へ引く 力が働いていると予想される.

（2）腸腰筋，身区幹筋などにより，股関節屈曲位，躯 幹前屈位とし重心を前方へ移動している.

（3）立脚中期には大殿筋により股関節が伸展し, 膝 関節を後方へ引く.

（4）膝関節屈曲位が保持できないため踏み切り動作 が小さい.

ことなどの代償メカニズムによると考えられた.

\section{文献}

1) 明石 謙：運動学，リハビリテーション医学全書. 医 歯薬出版株式会社. 東京, 1973.

2 ) Saunders, J.B., : The Major Determinants in Normal and Pathological Gait. J. Bone and Joint Surg., 35-A : 543-559, 1953.

対照者 SLOW WALKING

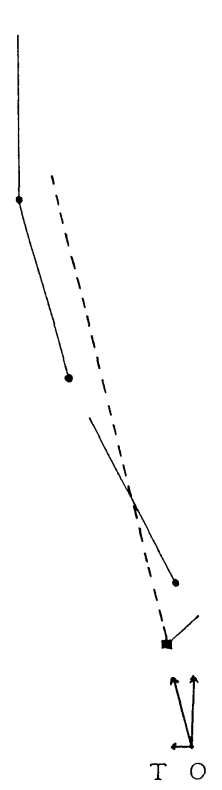

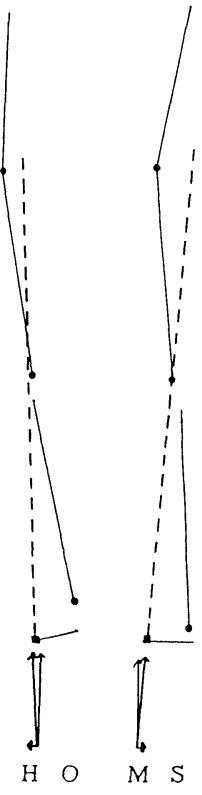

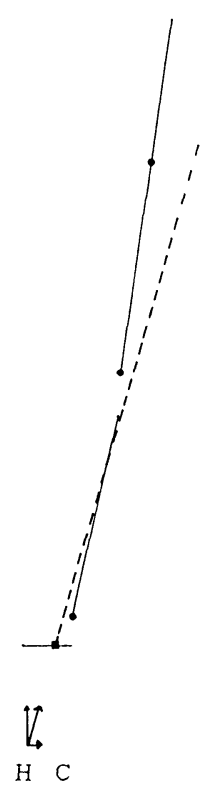

(MS : Mid Stance)

(HO : Heel off)

図－5 各関節に及ぼす床反力の影響 